\title{
GEOLOGIC MAP OF THE HILO 7 1/2' QUADRANGLE, ISLAND OF HAWAII
}

\author{
By J.M. Buchanan-Banks
}

\section{DISCUSSION}

\section{INTRODUCTION}

The Island of Hawaii has felt the effects of several kinds of geologic hazards during the past $150 \mathrm{yr}$, among them volcanic eruptions, earthquakes, floods, and tsunami inundations (U.S. Geological Survey, 1977; Mullineaux and others, 1987). As the population increases, so does the impact of such natural disasters. To understand the causes and reduce the effects of some of these hazards, geologic mapping in the populous area in and near the city of Hilo, the main cultural and political center on the island, was undertaken. The evaluation of earthquakerelated hazards and geologic causes of flooding in and near Hilo was presented in previous publications (Buchanan-Banks, 1983, 1987; Lockwood and BuchananBanks, 1981; Buchanan-Banks and Lockwood, 1982). Tsunami inundations, although infrequent, pose a great risk to life and property. Damaging tsunamis often result from distant earthquakes, but tsunamis have also been generated by local geologic events (U.S. Geological Survey, 1931; Macdonald and others, 1947; Eaton and others, 1961; Tilling and others, 1976; Moore and others, 1989). Few tsunamis, however, have been documented as resulting from eruptions (Cox and Morgan, 1977).

This report details the sources of the eruptive deposits and the history of flow chronology within the Hilo 7 $1 / 2$ ' quadrangle and discusses the associated volcanic hazards. Mapping was done on vertical aerial photographs taken in 1965 and 1977. Artificial cover, dense vegetation, and (or) steep or hazardous topography hampered mapping in many areas. Artificial cover was a significant problem in the Keaau area where young flows are made arable by covering them with a rockand-mud slurry. North of the Wailuku River, dense vegetation and precipitous banks interfered with data collection along many drainage channels. Similarly, bulldozed surfaces, lack of roads, and hazards posed by collapsed roofs of lava tubes concealed by dense vegetation hampered data collection in the eastern part of the quadrangle. Geologic contents in parts of the Piihonua and Mountain View quadrangles are added to the detailed geologic mapping of the Hilo quadrangle to permit plotting of sample localities that are pertinent to the geologic history of the Hilo quadrangle (see map note for specific information).

\section{Location}

The Hilo quadrangle is located along the east-central coast of the Island of Hawaii (fig. 1). Hilo, the major population center and only deep-water port on the east side of the island, lies within the quadrangle on the north- east flank of Mauna Loa Volcano at the head of Hilo Bay. Keaau, the next largest town in the southern part of the quadrangle, also lies on the northeast flank of Mauna Loa.

\section{Geography and Climate}

Most of the terrain surfaced by lava flows from Mauna Loa slopes gently downward from an elevation of about $1,260 \mathrm{ft}$ in the southwest corner of the quadrangle to sea level in the northeastern part. However, in the northwest corner, where the lava flows are from Mauna Kea Volcano, the terrain slopes east-southeastward from about 860-ft elevation toward the coast, where the deposits are truncated by wave-cut cliffs as much as $30 \mathrm{~m}$ high. The Wailuku River, in the northwestern part of the quadrangle, is the largest perennial river. North of the river, major streams flow from west to east in deeply incised channels. South of the river, streams generally flow northeastward, commonly along the margins of recent lava flows from Mauna Loa, and their channels range from distinct to amorphous. All stream channels to the south are shallow relative to the channels of the Wailuku River and streams farther north.

The climate is subtropical and average annual temperatures range from $18^{\circ}$ to $26^{\circ} \mathrm{C}$. Average annual rainfall is 330 to $445 \mathrm{~cm}$. Precipitation is usually greatest in the winter months and increases westward due to the prevailing northeast trade winds that force moisture-laden clouds to condense as they move upward along the mountain slopes (M\&E Pacific, Inc., 1980). The mild temperatures and ample rainfall result in dense vegetation and rapid weathering.

Sugarcane is the major agricultural product of the island. It is usually cultivated where volcanic ash deposits are thickest, but it is also grown on old aa flows that are only thinly surfaced. In many places, land once used for sugarcane is now being planted with orchards of macadamia nut trees.

\section{Other Studies}

The first maps of the Hilo area were navigational charts of Hilo Bay drawn by early European visitors to the island. The earliest published map was made in 1825 by C.R. Malden, cartographer with Lord Byron's expedition; it showed taro gardens, fishponds, and groves of coconut trees near the coast in the area between the Wailuku River and Reeds Bay (Kelly and others, 1981, p. 21; Kelly, 1982). Another map made in 1882 by G.E.G. Jackson and C.J. Lyons extended the mapped area northward along the Hamakua coast (fig. 1), north of the Hilo quadrangle, and eastward as far as Keokea Point (Kelly and others, 1981, fig. 30). The most notable 
difference between the two maps is a gridded street pattern shown on the later map where only taro fields had existed previously. A larger scale map showing. street names and other geographic features was produced by E.D. Baldwin in 1891 as part of a Hawaii Territory survey (Kelly and others, 1981, fig. 27). The first geologic map that included the quadrangle was a 1:125,000scale generalized geologic map of the Island of Hawaii by Stearns and Macdonald (1946). Baldwin (1953) in-

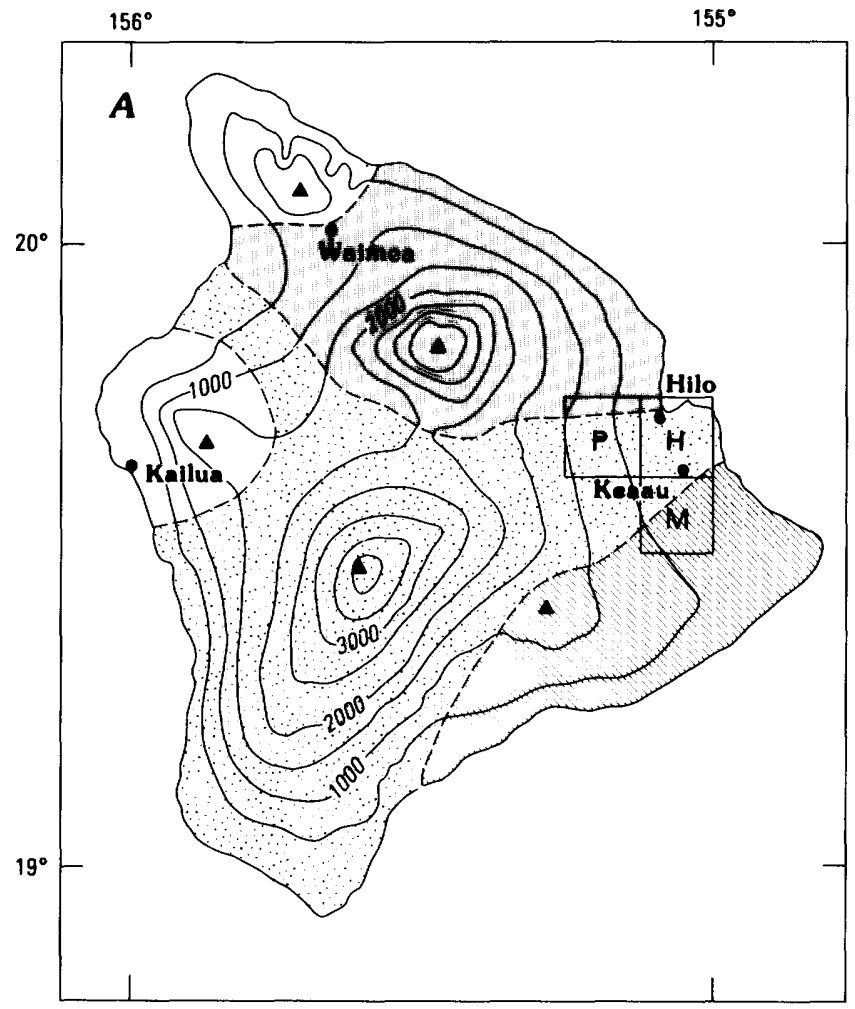

cluded in his description of the 1880-81 eruption a small-scale map of historic lava flows near Hilo. A geologic map of part of the Hilo and Piihonua quadrangles resulted from a study sponsored by the U.S. Army Corps of Engineers, Honolulu District, to mitigate flood damage along Alenaio Stream (Lockwood and Buchanan-Banks, 1982). A map showing thicknesses of volcanic ash deposits near Hilo included the northwestern part of the quadrangle (Buchanan-Banks, 1983).

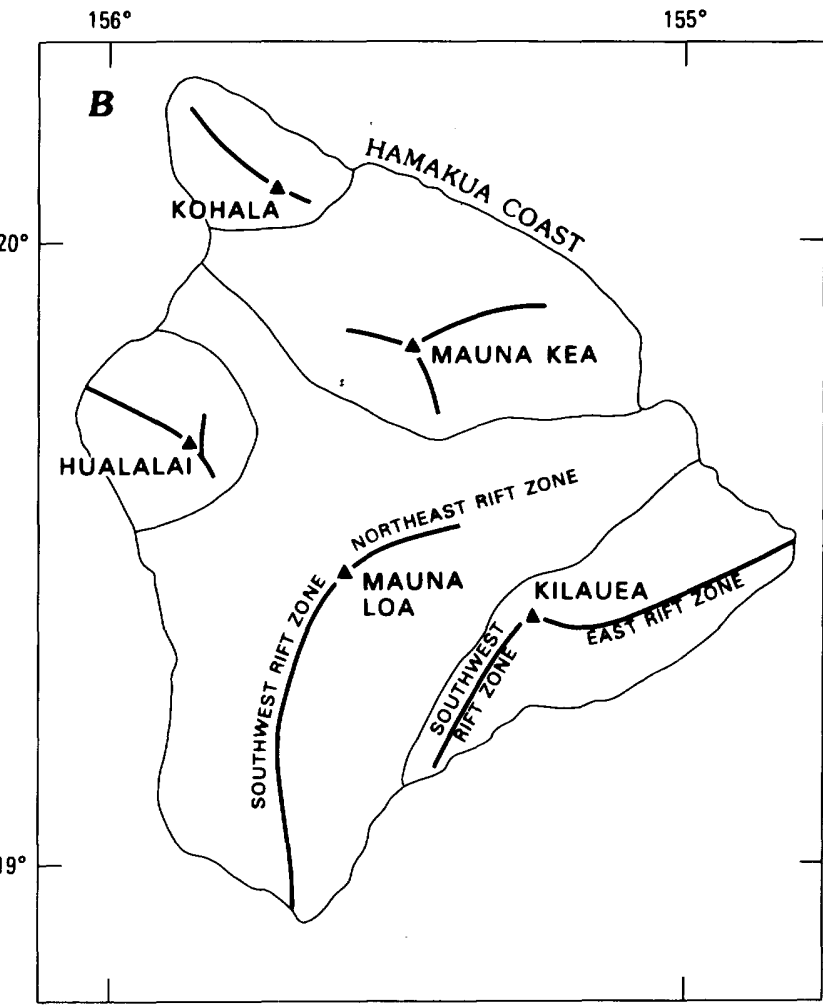

Figure 1. Island of Hawaii showing selected geographic and geologic features (modified from Peterson and Moore, 1987). A, Generalized topography and boundaries of five volcanoes; stipple pattern, lava flows chiefly from Mauna Loa; diagonal-line pattern, lava flows chiefly from Kilauea; shaded area, lava flows chiefly from Mauna Kea; unpatterned area, lava chiefly from Hualalai and Kohala. Three 7 1/2' quadrangles shown are P, Piihonua; $\mathrm{H}$, Hilo; and M, Mountain View. Contour interval 500 feet. B, Major rift zones; rift zones on Kilauea and Mauna Loa are named.

\section{GEOLOGY}

The map area is surfaced by basalt flows from three of the five volcanoes that form the Island of Hawaii. Most of the flows are from Mauna Loa, the others from Mauna Kea and Kilauea (fig. 1). The Wailuku River is the approximate boundary between the lava flows from Mauna Kea and those from Mauna Loa; a few outcrops of Mauna Kea basalt are located south of the river. A flow from Kilauea crops out only in the southeast corner of the map area, where it forms a thin veneer on Mauna Loa flows.

\section{Stratigraphic Framework}

The stratigraphic framework for volcanic rocks defined by Langenheim and Clague (1987) is followed in this report. Four main eruptive stages of Hawaii volcanism-preshield or initial, shield, postshield or capping, and rejuvenated-are recognized (Clague and Dalrymple, 1987; Peterson and Moore, 1987). Rocks of two of these stages, shield and postshield, are exposed within the map area. No preshield stage rocks are exposed and no rejuvenated stage rocks have yet been erupted.

Mauna Kea is the only volcano that deposited lava flows within the map area that has passed through the shield stage into the postshield stage. Rift zones on Mauna Kea are less well defined than those on Mauna Loa or Kilauea and are mainly suggested by westward, southward, and eastward alignments of cinder cones (fig. 1). Rocks of Mauna Kea are divided into the Hamakua Volcanics of Pleistocene age and the Laupahoehoe 
Volcanics of Pleistocene and Holocene age on the basis of potassium-argon ( $\mathrm{K}-\mathrm{Ar}$ ) and radiocarbon dating (Porter, 1979; Langenheim and Clague, 1987). Ash deposits separating Hamakua from Laupahoehoe are locally derived (Langenheim and Clague, 1987, p. 62). Hamakua rocks of the alkalic postshield stage are the only rocks exposed within the map area. Mauna Kea last erupted about 3.6 ka (Porter, 1979).

All exposed lava from Mauna Loa is shield-stage tholeilitic lava erupted mostly from the summit caldera and the southwest and northeast rift zones (fig. 1). Rocks of the volcano are divided into the Ninole Basalt and the Kahuku Basalt of Pleistocene age and the Kau Basalt of Pleistocene and Holocene age. The Kahuku and Kau generally are separated by the Pahala Ash of Pleistocene age (between about 30 to $10 \mathrm{ka}$ ) (Easton, 1987). Within the map area, only the Kahuku and Kau Basalts, erupted most likely from the northeast rift zone, are exposed; they are separated by a Pahala-type ash, herein informally called Homelani ash deposits (unit ha). The Kau Basalt consists of an historic member (19th century) and prehistoric members (14 to $0.6 \mathrm{ka}$ ).

The exposed lava from Kilauea, like that of Mauna Loa, is all shield-stage tholeitic lava erupted from the summit caldera and the southwest and east rift zones. Rocks of the volcano are divided into the Hilina Basalt of Pleistocene age and the Puna Basalt of Pleistocene and Holocene age, which are usually separated by the Pahala Ash. Only the Puna Basalt is found in the map area.

\section{Ash Deposits}

In the northwest corner of the Hilo quadrangle north of the Wailuku River, volcanic ash deposits, which are a few centimeters to several meters thick, cover most of the surface and overlie Hamakua age flows from Mauna Kea Volcano. South of the river, ash deposits are exposed discontinuously and are interbedded with some Mauna Loa flows.

Ash in the Hilo area is composed of air-fall deposits whose source has been variously ascribed to Mauna Kea, Mauna Loa, or Kilauea, and sometimes to all three volcanoes. Wentworth $(1938$, p. 57,72$)$ considered the ash on the southeast flank of Mauna Kea and in Hilo to be the product of all the pyroclastic material erupted at the numerous vents on the summit and flanks of Mauna Kea, and he called it the Waiau formation; it contains a cinder-cone phase and a yellow-tuff phase representing the near and far deposits of a single unit, respectively. Wentworth regarded the yellow-tuff phase as equivalent to ash deposits near Pahala. Stearns and Macdonald (1946, p. 157) called the thick ash deposits in the Hilo area the Pahala ash and reported that although the greatest thickness of ash accumulated from eruptions on Mauna Kea, small contributions to its bulk must have resulted from eruptions on neighboring volcanoes. Fraser (1960, p. B355), however, concluded that the "...Pahala ash on the lower...southeast slope of Mauna Kea came from Kilauea...." There are no stratigraphic studies that define the provenance of the ash, probably because deep weathering has altered most of the original constituents to gibbsite, allophane, and locally halloysite (Bates, 1960; Wieczorek and others, 1982). However, recent mapping on Mauna Kea indicates that the surficial ash deposits were locally derived and are genetically distinct from the Pahala Ash on Kilauea and Mauna Loa (E.W. Wolfe, oral commun., 1987). A history of episodic deposition and weathering of the ash is suggested both from field observations and from laboratory measurements of physical properties (BuchananBanks, 1983; Wieczorek and others, 1982). The ash deposits are color banded, and some textural differences are observable from bed to bed. Each bed may record a separate eruption; alternatively, the beds could reflect one or more voluminous eruptions that have changing ejected grain size or transportation mechanics, or differing response of various layers to weathering, or both. Some deposits are reworked by wind and water. Undisturbed ash deposits are weakly cemented and resistant to erosion; they form steep road cuts (slope more than $60^{\circ}$ ) that reflect the high angle of internal friction of the material $\left(40^{\circ}-43^{\circ}\right)$. Their mechanical properties are similar to those of ash deposits near Pahala, about $72 \mathrm{~km}$ to the southwest (Ray Wilson, written commun., 1979).

While only a single bed of ash about 1 to $2 \mathrm{~cm}$ thick has been found between Mauna Kea lava flows within the Wailuku River channel, ash beds between Mauna Loa lava flows are more common. The relation between some ash deposits and lava flows indicates that ash was deposited throughout a period of at least 10,000 yr. The younger pahoehoe flow of Waipahoehoe Stream (unit Ik1wy, $23.8 \mathrm{ka}$ ) overlies an ash deposit that may or may not be reworked. The existence of ash beneath this unit indicates that explosive eruptions were depositing ash in and near the map area at least as long ago as 24,000 yr B.P. The thickest section of Homelani ash deposits (unit ha) found in the Hilo quadrangle is exposed in the Wailuku River, where it is overlain by the pahoehoe flow of Waianuenue Avenue (unit Ik2wa, $14.2 \mathrm{ka}$ ); this deposit of Homelani ash most likely represents an accumulation of all ash falling during an interval uninterrupted by lava flows. Ash deposits also overlie the pahoehoe flow of Waianuenue Avenue (unit Ik2wa), and lie beneath flows younger than 14,000 yr B.P., but most of these deposits are thin and some have probably been reworked by wind and water.

\section{Tephra Cones and Structure}

Three spatter-and-cinder cones and associated lava flows are located just south of the Wailuku River. The cones, the largest of which is named Halai, trend northeastward and probably formed when fountain activity along a single fissure vent became localized to a few centers. The cones are about $35 \mathrm{~m}$ high and are blanketed by Homelani ash deposits, thus establishing their age as older than about $14 \mathrm{ka}$. Chemical analyses of spatter (Lockwood and Buchanan-Banks, unpub. data, 1979) and flow samples (table 2, Map Nos. C57 and C58) confirm that the cones and lava flows are eruptive products of Mauna Loa, as suggested by Stearns and Macdonald (1946, p. 70).

Other cinder cones, uncovered during land clearing and later quarried for their cinder, have been described in the Piihonua quadrangle just west of the Hilo quad- 
rangle boundary (Macdonald and Eaton, 1964; see map for approximate location of vent or vents). Macdonald and Eaton (1964, p. 157) reported "...a line of small cinder-and-spatter cones alined east-northeast parallel to the northeast rift zone of Mauna Loa," which are, however, in a later publication described as "...one small spatter cone..." (Macdonald and others, 1983, p. 369). Charcoal material found among the cinder and spatter at this site has an average radiocarbon age of $2.0 \pm 0.25$ ka (Macdonald and Eaton, 1964, p. 157).

The northeast rift zone of Mauna Loa trends toward Hilo (fig. 1) and could be the source of the spatter-andcinder cones. However, gravity measurements (Kinoshita and others, 1963; Daniel Dzurisin, unpub. data, 1979), aeromagnetic and electrical surveys (Flanigan and Long, 1987), and other geophysical studies (Hill and Zucca, 1987 ) indicate that the most likely location of this rift zone is southeast of the map area between Keaau and Pahoa, about $16 \mathrm{~km}$ to the southeast. The cones south of Wailuku River and in the Piihonua quadrangle, therefore, probably represent short-lived eruptions widely separated through time that occurred along a radial fissure or fissures of the northeast rift zone.

\section{Ages of Lava Flows}

Ages of flows are well established for historic flows and flows dated by radiocarbon methods. Twenty-five samples of carbonized roots and other plant material were collected from beneath 14 prehistoric Mauna Loa flows and analyzed (table 1). Ages of most other flows and ash deposits are constrained by stratigraphic relations to dated flows.

Directions of remanent magnetization were used to correlate isolated flow outcrops and suggest approximate ages of some flows not dated by radiocarbon techniques (table 3). Comparison between magnetic direction of a rock of unknown age to the local geomagnetic history provides a possible age or ages for the unknown rock.

\section{Morphology of Lava Flows}

Both aa and pahoehoe are present; aa flows surface more than half the map area. Within the map area, aa flows are usually broader and thicker than pahoehoe flows. Aa flows are defined by rough, rubbly, and generally clinkery surfaces. Steep exposures in stream banks or road and construction cuts commonly show one or more massive units in the flow interior. Where the base is exposed, rubble is generally present. Some aa flows enclose small pahoehoe pads that represent outbreaks of more fluid lava from channels that fed the advancing flow or from the fluid lava core within the flow interior. Such outbreaks have been observed during historic eruptions, as in the January 1983 eruption of Kilauea Volcano (Buchanan-Banks, unpub. data, 1983; Wolfe and others, 1988).

Pahoehoe is defined by a smooth, undulating, and locally wrinkled or ropey surface. Within the map area, pahoehoe flows were fed by lava tubes whose formation probably reflect prolonged eruptive activity or low viscosity lava, or both. Tubes, commonly less than 0.5 $\mathrm{m}$ to several meters in diameter, now provide pathways for subsurface water, which can cause flooding in Hilo during periods of intense rainfall upslope. Young pahoehoe flows have well-preserved, shiney, black surface glass whose quality of preservation declines with age. Flows older than about 4 ka have little to no preserved surface glass.

Vesicles are present in both aa and pahoehoe flows. Aa flows have fewer and generally larger vesicles; they are commonly irregular in shape and compose as much as $\mathbf{1 5}$ percent of the rock at the flow surface. Most pahoehoe flows are moderately to highly vesicular; spherical to subspherical vesicles constitute about 15 to 40 percent of the near-surface rock, but a few flows have vesicles that constitute nearly 50 to 60 percent. Where flows are closely associated with ash deposits, vesicles commonly are filled with weathered residue.

\section{Lava Flows from Mauna Kea Volcano}

In the northwest corner of the map area, the alkalic basalt flows of the Hamakua Volcanics of Mauna Kea are covered by Homelani ash deposits, producing a subdued morphology. South of the Wailuku River, the ash and lava flows are locally covered by thoelitic basalt flows from Mauna Loa. No interfingering of Mauna Kea and Mauna Loa lava flows has been found in the map area; all of the Mauna Kea flows are apparently older than all of the exposed Mauna Loa flows.

Most Mauna Kea flows that lie directly beneath the ash are so deeply weathered that they can easily be broken with a shovel, which indicates that a long period of subaerial weathering occurred prior to deposition of the ash. Mauna Kea flows are weathered more severely than flows of Mauna Loa known to be at least 24 ka, suggesting that the Mauna Kea flows are substantially older. Pahoehoe flows generally exhibit greater weathering than aa flows of the same or younger age, probably because the greater vesicularity of pahoehoe provides more avenues for percolation of water and, therefore, more rapid weathering. However, rubble at the tops and bottoms of aa flows directly beneath the ash also show deep weathering, which has locally produced saprolite consisting of well-rounded to subangular rock remnants in a clay matrix (Buchanan-Banks, 1983). The saprolite is less developed in the dense central part of the flows, where spheroidal weathering predominates. Commonly, zones of earthy residue about $1 \mathrm{~cm}$ wide surround the remnant spheres and represent solution channels along which leaching has occurred (Bates, 1962).

Hamakua flows are exposed in the north bank, and locally in the south bank, of the Wailuku River channel. Because of limited lateral extent of flows, difficult access, and small likelihood of correlating flows from stream to stream, only a few of the Hamakua Volcanics are subdivided into mappable flows. Two flows that crop out most extensively are the aa flow of Puu loane (unit khpi), which can be traced from the Piihonua quadrangle into the Hilo quadrangle and the plagioclase-phyric aa flow of Kiohoole Gulch (unit khkg), which is exposed in the bed of the Wailuku River. Other outcrops are exaggerated to show on map. 


\section{Lava Flows from Mauna Loa Volcano}

Tholeiitic lava of the Kau and Kahuku Basalts of Mauna Loa erupted from vents southwest of the map area on the northeast rift zone (fig. 1) are the predominant surface flows south of the Wailuku River. The oldest lava flows are exposed in the beds of ephemeral streams near the west edge of the Hilo quadrangle and in Alenaio Stream to the northeast.

West of Hawaii Highway 11 and north of Stainback Highway, most flows form narrow northeast-trending units covering from less than 0.5 to as much as 8.0 $\mathrm{km}^{2}$. However, aa flows of Ainaola Drive (unit lk2ad) cover an area of about $18 \mathrm{~km}^{2}$.

Two basalt flows from Mauna Loa are exposed along the south side of the Wailuku River and locally overlie Mauna Kea flows. The Waianuenue Avenue pahoehoe flow (unit $1 \mathrm{k} 2 \mathrm{wa}$ ) is situated about 12 to $13 \mathrm{~m}$ above the present-day river level and locally occupies relatively shallow channels cut by the ancestral river in the underlying ash and saprolite deposits. Emplacement of this flow generally shifted the course of the river northward. Some 4,000 yr later, the aa flow of Rainbow Falls (unit Ik2rf) was erupted and, upon reaching the river, followed this northern channel that had been substantially deepened during the intervening years. From the west Hilo quadrangle boundary to Rainbow Falls, the aa incompletely filled the channel, causing only minor disruption of the drainage along this reach of the river. East of the falls, however, the ancestral channel of the Wailuku was blocked by the aa, and the river was forced northward once again. This part of the present-day river has cut through the weakly indurated ash and weathered lava flows from Mauna Kea during about the past 10,000 yr. The abandoned channel can be seen along the south bank of the river at Rainbow Falls and again south of Reeds Island.

As many as five other lava flows, which have a total thickness of about $6 \mathrm{~m}$, crop out in the south bank of the river beneath the abutments of the bridges east of Hawaii Highway 19 bridge, but are too small to show at this map scale. Field evidence to establish the relation of these pahoehoe flows to either Mauna Kea or Mauna Loa Volcano is obscured by the aa flow of Rainbow Falls (unit Ik2rf). The flows are considered to derive from Mauna Loa because (1) they lack correlative outcrops in the north bank of the river where flows from Mauna Kea crop out, (2) they are less weathered than most Mauna Kea flows, and (3) chemical analysis on pahoehoe flow of Mokupane Point (unit $1 \mathrm{k} 1 \mathrm{mp}$ ) (table 2, Map No. C56) indicates it is a Mauna Loa flow. Because they apparently lie beneath the Homelani ash deposits (unit ha), these pahoehoe flows are considered to be older than $14 \mathrm{ka}$.

The southwestern and eastern parts of the map area are surfaced by the Panaewa Forest Reserve lava flows (unit k/2pf) that compose four very large flow unitstwo aa (Ik2pf4 and /k2pf3) and two pahoehoe (Ik2pf2 and Ik2pf1) flows; each aa also has a minor pahoehoe phase. Because the flows are mineralogically similar and the terrain has been heavily modified by bulldozers, con- tacts are difficult to recognize; the flows were largely mapped by photogeologic interpretation. Variations in directions of remanent magnetization between the units are small, indicating that the flows were erupted closely in time. Also, similar spatial distributions suggest that the units were erupted from the same location. The unit probably represents a single, prolonged eruptive episode that tapped more than one magma reservoir, as evidenced by mineralogic and chemical differences between individual flow units. Such a sustained and voluminous eruption, depositing about 0.2 to $0.3 \mathrm{~km}^{3}$ of lava within the Hilo quadrangle alone, is likely to have caused subsidence or possibly caldera collapse at the summit of Mauna Loa due to withdrawal of magma and subsequent loss of support (Holcomb and others, 1988).

In the southernmost part of the Hilo quadrangle near Keaau, most lava flows of Mauna Loa are about $5.2 \mathrm{ka}$ and older; an exception is the apparently younger aa flow at the boundary with the Mountain View quadrangle (unit $1 \mathrm{k} 2 \mathrm{mv}$ ). East of Keaau, four small exposures of a lava flow separated from the overlying flows by a moderately indurated, baked-looking red-brown ash deposit about 1 to $2 \mathrm{~cm}$ thick, are mineralogically similar to the aa flows of Ainaola Drive (unit Ik2ad) in the western part of the map area and are tentatively correlated with that unit.

\section{Lava Flow from Kilauea Volcano}

A lava flow of the Puna Basalt, probably from the Ai-laau shield of Kilauea Volcano and called the Old Volcano Trail flow (unit kipvt) by Holcomb (1987, fig. $12.5 \mathrm{~A}, \mathrm{I}$, and J) forms a thin veneer over Mauna Loa flows in the southeast corner of the map area. More than one flow may be present, but possible contacts are obscured by deposits of slurry.

\section{CHEMISTRY AND PETROGRAPHY}

All lava flows from Mauna Kea are composed of alkalic basalt. These rocks are chemically typical of the basalts erupted during the postshield stage. The lava flows are fairly homogenous in their mineral compositions but show chemical diversity (table 2; Buchanan-Banks, 1991). The silica content (in weight percent) of the flows averages about 44 percent and ranges from nearly 41 percent in picritic basalt to slightly more than 47 percent in alkalic basalt. Most flows are slightly porphyritic, have an aphanitic groundmass, and are light gray. A few flows contain narrow bands of darker material that probably resulted from chemical weathering along hairline fractures. The most common phenocryst and microphenocryst is lath-shaped plagioclase, which composes less than 0.5 to as much as 6 percent of some flows; one flow contains 12 percent plagioclase. Most flows contain as much as 3 percent olivine as phenocrysts and microphenocrysts, and one picritic basalt contains 48 percent olivine. Phenocrysts and microphenocrysts of opaque minerals and pyroxene are generally less abundant. Stellate cumulocrysts of microphenocrystic plagioclase commonly are found 
with pyroxene and olivine microphenocrysts. Several flows show slight alignment of the plagioclase laths along flow directions; a few flows have trachytic texture. The most common groundmass mineral is plagioclase, whose laths are slightly oriented parallel to flow direction; olivine and other mafic and opaque minerals fill the interstices between the plagioclase laths, and apatite is commonly present as an accessory mineral.

All lava flows from Mauna Loa and Kilauea Volcanoes are also of basaltic composition, but they can be chemically distinguished from the flows of Mauna Kea by their higher silica and lower alkali content (table 2; Buchanan-Banks, 1991). The silica content of these flows averages almost 50 percent and ranges from nearly 47 percent silica in picritic basalt to slightly more than 52 percent in tholeiitic basalt. Most flows are porphyritic, have a microcrystalline to aphanitic groundmass, and are medium to dark gray. They are characterized by phenocrysts of olivine and plagioclase and minor amounts of pyroxene; microphenocrysts of hypersthene are present in a few flows. Most flows contain 1 to 5 percent olivine as euhedral to subhedral phenocrysts and microphenocrysts, but some contain 10 to 30 percent; a few picritic basalts contain as much as 42 percent olivine. Phenocrysts and microphenocrysts of plagioclase, usually lath shaped, constitute 1 to 5 percent of a flow, but a few flows contain about 10 percent plagioclase, and one flow contains as much as 21 percent. Cumulocrystic intergrowths of olivine and plagioclase are found in about one-half of the flows; pyroxene is locally present. In the groundmass, small grains of olivine, mafic and opaque minerals, and devitrified glass heavily dusted with opaque minerals, fill interstices between plagioclase laths. Moderately to heavily porphyritic basalt flows are present in both the Kau and Kahuku Basalts of Mauna Loa.

\section{VOLCANIC HAZARDS}

The Island of Hawaii is primarily the product of volcanic processes (Mullineaux and others, 1987), and future volcanic processes are likely to be similar to those that occurred in the past. An understanding of these processes and the likelihood of their occurrence can be used to evaluate the hazards they present to life and property, and to help minimize their effects.

Geologic mapping indicates that during the past few thousand years the most common volcanic process posing a hazard within the map area is sustained eruptions of Mauna Loa that would send lava flows into the area. Air-fall ash deposits resulting from explosive eruptions and tephra cones resulting from localized fissure-vent eruptions have also been mapped within the map area but are considered less likely to occur.

\section{Lava Flows}

The 1880-81 pahoehoe flow from Mauna Loa Volcano is the most recent flow to enter the map area. In the past, lava flows from Mauna Loa entered the map area at least seven times during the past 2,000 yr, averaging a flow every $285 \mathrm{yr}$; at least 20 times during the past $10,000 \mathrm{yr}$, averaging a flow every $500 \mathrm{yr}$; and at least 25 times during the past $24,000 \mathrm{yr}$, averaging a flow every $960 \mathrm{yr}$. These recurrence intervals do not necessarily mean that Mauna Loa has been erupting more frequently during the past 2,000 yr, but rather they reflect the fact that more of the older flows are covered by recent eruptive material, and the few small outcrops that remain are often obscured by agriculture and construction projects. Of the 25 radiocarbon samples collected (table 1), 18 samples were from beneath 11 different lava flows younger than $11 \mathrm{ka}$, while only seven samples were obtained from beneath three lava flows older than about $14 \mathrm{ka}$.

Lava flows represent localized hazards to property directly in their path but seldom to life because of the generally gentle eruptive behavior of Hawaiian volcanoes. Most Mauna Loa lava flows within the map area form narrow northeast-trending outcrops, usually about 1 to $2 \mathrm{~km}$ wide and less than $10 \mathrm{~km}$ long. However, examples of more voluminous flows do exist within the area. Lava flows of Ainaola Drive and Panaewa Forest Reserve (units Ik2ad and Ik2pf, respectively) are unique in the large areas they surface; these flows probably represent prolonged or high-volume eruptions, or both. Were a flow of analogous volume to enter the map area in the future, it would cause widespread damage. However, future eruptions are more likely to be similar in size to most past eruptions, which means that smaller lava flows are more likely.

The location of the erupting vent along the rift zone seems to affect the direction in which lava travels. Lavas from vents located north of the northeast rift zone's broad topographic axis travel northeastward toward Hilo. Recent studies indicate that with few exceptions each of the five successive historical eruptions $(1852,1855-$ $56,1880-81,1942$, and 1984) from this rift zone has occurred farther southeast than the preceding one. If this pattern persists, lavas from future eruptions will likely flow predominantly southeastward away from Hilo (Lockwood, 1990).

\section{Ash Deposits}

Although Hawaiian volcanoes usually erupt gently, the existence of ash deposits and historic accounts confirm that explosive eruptions do occur. Within the map area, Homelani ash deposits represent an accumulated thickness of air-fall tephra most of which was deposited prior to 14,000 yr B.P. but some of which may have been deposited since that time. Ash deposits are found beneath flows as young as $600 \mathrm{yr}$ B.P.; however, these younger deposits may be reworked material. While it is reasonable to assume that the greatest accumulation of ash within the map area is from Mauna Kea, contributions from Kilauea and Mauna Loa cannot be ruled out. The most recent ash eruption from Mauna Kea occurred about $3,600 \mathrm{yr}$ B.P. from the south rift zone; ash deposits were confined to the higher altitudes of the volcano (Porter, 1979, p. 1088). About 1 percent of the prehistoric and historic eruptions of Kilauea Volcano have been explosive (Decker and Christiansen, 1984). During the past 2,000 yr, materials from ash-producing eruptions 
of Kilauea were deposited within about $20 \mathrm{~km}$ of the summit (Daniel Dzurisin, written commun., 1988; Swanson and Christiansen, 1973; Jaggar and Finch, 1924). Mauna Loa apparently rarely erupts explosively. Although none of the recent explosive eruptions deposited tephra in the map area, the area is only about $60 \mathrm{~km}$ from the summit of Mauna Loa and $40 \mathrm{~km}$ from the summits of Kilauea and Mauna Kea. Certain wind conditions could result in Hilo receiving anywhere from 5 to $100 \mathrm{~cm}$ of ash from an explosive eruption of any of these volcanoes (Blong, 1984, p. 29, figs. 2-11).

Tephra eruptions represent a widespread hazard mainly to property, but they could also present health hazards to humans and animals. Some hazards from ash falls include contamination of water supply, damage to health of livestock through ingestion of ash and grinding down of teeth, breathing difficulties in humans and animals, damage to engines from ash abrasiveness, interruption of communications, and halting of transportation. Thick ash accumulation can cause roofs to collapse and can also smother trees and crops, disrupt commerce, and clog waterways. The absence of any documented young ash-fall deposits in the map area suggests that a large-scale event of this nature is unlikely.

\section{Vents and Cones}

Vents are located along structural weaknesses in the crust of the volcano where magmatic pressures cause ground cracks, fissures, and craters. Spatter-and-cinder cones are formed when the eruptive activity becomes restricted to a few closely spaced centers. The 0.8$\mathrm{km}$-long fissure vent that produced cones such as Halai last erupted more than 14,000 yr B.P.; to the southeast in the Piihonua quadrangle (fig. 1) another vent eruption possibly occurred only about 2,000 yr B.P. Young lava flows that cover the area between the two exposed vents may hide other vent deposits.

Erupting vents represent localized hazards mostly to property, but people near the erupting vents can be injured by falling hot spatter. Present evidence suggests that the lower $50 \mathrm{~km}$ of the northeast rift zone has been inactive for the past 2,000 yr (Lockwood, 1979). It may be that compression of the northeast flank of Mauna Loa between Mauna Kea and the growing mass of Kilauea Volcano has reduced the likelihood of future eruptions along this zone (Holcomb and others, 1988).

\section{ACKNOWLEDGMENTS}

V. C. Taylor ably assisted with field and office work. The author is indebted to the following U.S. Geological Survey personnel: Meyer Rubin for analyses of charcoal materials; J.P. Lockwood and D.E. Champion for data on remanent magnetization of lava flows; N.G. Banks and C.A. Gardner for consultations on thin-section analysis and review of rock descriptions; and to R.T. Okamura, Assistant Scientist-in-charge, and other staff of the USGS Hawaiian Volcano Observatory. Several parts of the field study benefited from special knowledge supplied by J.P. Lockwood. M.O. McWilliams (Stanford University), provided additional data on remanent magnetization of lava flows.

\section{REFERENCES CITED}

Baldwin, E.D., 1953, Notes on the 1880-81 lava flow from Mauna Loa: U.S. Geological Survey, The Volcano Letter, no. 520, p. 1-3.

Bates, T.F., 1960, Rock weathering and clay formation in Hawail: University Park, Pennsylvania State University Bulletin, College of Mineral Industries, v. 29 , no. 8,4 p.

1962, Halloysite and gibbsite formation in Hawaii, in Swineford, Ada, and Franks, P.C., eds., Clays and clay minerals, v. 9, National Conference on Clays and Clay Minerals, 9th, Lafayette, Ind., October 5-8, 1960, Proceedings: New York, Pergamon Press, p. 315-328.

Blong, R.J., 1984, Volcanic hazards: Orlando, Fla., Academic Press, $424 \mathrm{p}$.

Buchanan-Banks, J.M., 1983, A reconnaissance map showing thicknesses of volcanic ash deposits in the greater Hilo area, Hawaii: U.S. Geological Survey Miscellaneous Field Studies Map MF-1499, scale 1:24,000.

1987, Structural damage and ground failures from the November 16, 1983, Kaoiki earthquake, Island of Hawaii, chap. 44 in v. 2 of Decker, R.W., Wright, T.L., and Stauffer, P.H., eds., Volcanism in Hawaii: U.S. Geological Survey Professional Paper 1350, p. 1187-1220.

___ 1991, Petrochemistry of the Hilo $71 / 2^{\prime}$ quadrangle, Island of Hawaii: U.S. Geological Survey Open-File Report 91-626, 24p.

Buchanan-Banks, J.M., and Lockwood, J.P., 1982, Geologic map of the Alenaio-Waipahoehoe Stream area, South Hilo District, Hawaii: U.S. Geological Survey Open-File Report 82-655, scale 1:24,000.

Buchanan-Banks, J.M., Lockwood, J.P., and Rubin, Meyer, 1989, Radiocarbon dates for lava flows from northeast rift zone of Mauna Loa Volcano, Hilo 7 $1 / 2$ quadrangle, Island of Hawaii: Radiocarbon, v. 31 , no. 2 , p. $179-186$

Clague, D.A., and Dalrymple, G.B., 1987, Geologic evolution, pt. I in The Hawalian-Emperor volcanic chain, chap. 1 in v. 1 of Decker, R.W., Wright, T.L., and Stauffer, P.H., eds., Volcanism in Hawaii: U.S. Geological Survey Professional Paper 1350 , p. 5-54.

Coe, R.S., Grommé, Sherman, and Mankinen, E.A., 1978, Geomagnetic paleointensities from radiocarbon-dated lava flows on Hawaii and the question of the Pacific nondipole low: Journal of Geophysical Research, v. 83, no. B4, p. 1740-1756.

Cox, D.C., and Morgan, Joseph, 1977, Local tsunamis and possible local tsunamis in Hawaii: University of Hawaii, Hawaii Institute of Geophysics, HIG-77-14, $118 \mathrm{p}$.

Decker, R.W., and Christiansen, R.L., 1984, Explosive eruptions of Kilauea Volcano, Hawaii, in Explosive volcanism: inception, evolution and hazards: Washington, D.C., National Research Council, National Academy Press, p. 122-132. 
Easton, R.M., 1987, Stratigraphy of Kilauea Volcano, chap. 11 in v. 1 of Decker, R.W., Wright, T.L., and Stauffer, P.H., eds., Volcanism in Hawaii: U.S. Geological Survey Professional Paper 1350, p. 243260.

Eaton, J.P., Richter, D.H., and Ault, W.U., 1961, The tsunami of May 23, 1960, on the Island of Hawaii: Selsmological Society of America Bulletin, v. 51 , no. 2 , p. $135-157$.

Flanigan, V.J., and Long, C.L., 1987, Aeromagnetic and near-surface electrical expression of the Kilauea and Mauna Loa volcanic rift systems, chap. 39 in v. 2 of Decker, R.W., Wright, T.L., and Stauffer, P.H., eds., Volcanism in Hawaii: U.S. Geological Survey Professional Paper 1350, p. 935-946.

Fraser, G.D, 1960, Pahala Ash-an unusual deposit from Kilauea Volcano, Hawaii: U.S. Geological Survey Professional Paper 400-B, p. B354-B355.

Greeley, Ronald, 1974, Kaumana lava tube, in Greeley, Ronald, ed., Geologic guide to the Island of Hawaii-a field guide for comparative planetary geology: Washington, D.C., National Aeronautics and Space Administration, p. 234-238.

Hawaii County Board of Water Supply, 1971, Water master plan: Hawaii County Board of Water Supply, December, $68 \mathrm{p}$.

Hill, D.P. and Zucca, J.J., 1987, Geophysical constraints on the structure of Kilauea and Mauna Loa Volcanoes and some implications for seismomagmatic processes, chap. 37 in v. 2 of Decker, R.W., Wright, T.L., and Stauffer, P.H., eds., Volcanism in Hawaii: U.S. Geological Survey Professional Paper 1350, p. 903-917.

Holcomb, R.T., 1987, Eruptive history and long-term behavior of Kilauea Volcano, chap. 12 in v. 1 of Decker, R.W., Wright, T.L., and Stauffer, P.H., eds., Volcanism in Hawaii: U.S. Geological Survey Professional Paper 1350, p. 261-350.

Holcomb, R.T., Champion, D.E., and McWilliams, M.O., 1986, Dating recent Hawaiian lava flows using paleomagnetic secular variation: Geological Society of America Bulletin, v. 97, no. 7, p. 829-839.

Holcomb, R.T., Moore, J.G., Lipman, P.W., and Belderson, R.H., 1988, Voluminous submarine lava flows from Hawaiian volcanoes: Geology, v. 16, no. 5, p. 400-404.

Jagger, T.A., and Finch, R.H., 1924, The explosive eruption of Kilauea in Hawaii, 1924: American Journal of Science, ser. 5, v. 8, p. 353-374.

Kelly, Marion, 1982, Some background history of Alenaio Stream and the Hilo Boarding School ditch, Hilo, Hawaii, in Archaeological and historical studies for the Alenaio Stream flood damage reduction study, Hilo, Hawaii: Honolulu, Hawaii, Bernice P. Bishop Museum, Department of Anthropology, p. 1-29. [Prepared for U.S. Army Engineer District, Honolulu, Contract no. DACW84-82-M-0165.]

Kelly, Marion, Nakamura, Barry, and Barrere, D.B., 1981, Hilo Bay: a chronological history: Honolulu, Hawaii, Bernice P. Bishop Museum, Department of Anthro- pology, 341 p. [Prepared for U.S. Army Engineer District, Honolulu, Contract no. DACW84-80-C0015.]

Kelley, M.L., Spiker, E.C., Lipman, P.W., Lockwood, J.P., Holcomb, R.T., and Rubin, Meyer, 1979, U.S. Geological Survey, Reston, Virginia, radiocarbon dates XV: Mauna Loa and Kilauea Volcanoes, Hawaii: Radiocarbon, v. 21, no. 2, p. 306-320.

Kinoshita, W.T, Krivoy, H.L., Mabey, D.R., and MacDonald, R.R., 1963, Gravity survey of the Island of Hawaii: U.S. Geological Survey Professional Paper 475-C, p. C114-C116.

Langenheim, V.A.M., and Clague, D.A., 1987, Stratigraphic framework of volcanic rocks of the Hawaiian Islands, pt. II in The Hawaiian-Emperor volcanic chain, chap. 1 in v. 1 of Decker, R.W., Wright, T.L., and Stauffer, P.H., eds., Volcanism in Hawaii: U.S. Geological Survey Professional Paper 1350 , p. 55-84.

Lockwood, J.P., 1979, Geologic asymmetry of the northeast rift zone of Mauna Loa Volcano, Hawaiievidence for a mobile south flank [abs.]: Hawaii Symposium on Intraplate Volcanism and Submarine Volcanism, Hilo, Hawaii, July 16-22, 1979, Abstract Volume, p. 170.

-1990, Implications of historical eruptive-vent migration on the northeast rift zone of Mauna Loa Volcano, Hawaii: Geology, v. 15 , no. 7, p. 611613.

Lockwood, J.P., and Buchanan-Banks, J.M., 1981, Preliminary geologic report for the Alenaio Stream flood damage reduction study area, Hilo, Hawaii: U.S. Geological Survey Open-File Report 81-791, scale $1: 24,000,12 \mathrm{p}$.

1982, Geologic map of the Alenaio-Waipahoehoe Stream lower drainage area, in Harbors and rivers in Hawaii, Alenaio Stream, Island of Hawaii, Hawaii: Ft. Shafter, Hawaii, U.S. Army Engineers District, Honolulu, scale $1: 24,000$, p. C-4 to C6.

Macdonald, G.A., 1949, Petrography of the Island of Hawaii: U.S. Geological Survey Professional Paper 214-D, $96 \mathrm{p}$.

Macdonald, G.A., Abbott, A.T., and Peterson, F.L., 1983, Volcanoes in the sea, geology of Hawaii island: Honolulu, University of Hawaii Press, 517 p.

Macdonald, G.A., and Eaton, J.P., 1964, Hawaii volcanoes during 1955: U.S. Geological Survey Bulletin 1171, $170 \mathrm{p}$.

Macdonald, G.A., Shepard, F.P., and Cox, D.C., 1947, The tsunami of April 1, 1946, in the Hawaiian Islands: Pacific Science, v. 1, no. 1, p. 21-37.

M\&E, Inc., 1980, Hilo area comprehensive studygeological, biological and water quality investigations of Hilo Bay: Honolulu, Hawaii, p. iv-1 to iv-3. [Prepared for U.S. Army Engineer District, Honolulu.]

Moore, J.G., Clague, D.A., Holcomb, R.T., Lipman, P.W., Normark, W.R., and Torresan, M.E., 1989 , Prodigious submarine slides on the Hawailan Ridge: 
Journal of Geophysical Research, v. 94, no. B12, p. 17,465-17,484.

Mullineaux, D.R., Peterson, D.W., and Crandell, D.R., 1987, Volcanic hazards in the Hawaiian Islands, chap. 22 in v. 1 of Decker, R.W., Wright, T.L., and Stauffer, P.H., eds., Volcanism in Hawaii: U.S. Geological Survey Professional Paper 1350, p. 599621.

Peterson, D.W., and Moore, R.B., 1987, Geologic history and evolution of geologic concepts, Island of Hawaii, chap. 7 in v. 1 of Decker, R.W., Wright, T.L., and Stauffer, P.H., eds., Volcanism in Hawaii: U.S. Geological Survey Professional Paper 1350, p. 149189.

Porter, S.C., 1979, Quaternary stratigraphy and chronology of Mauna Kea, Hawail: a 380,000-yr record of mid-Pacific volcanism and ice-cap glaciation: summary: Geological Society of America Bulletin, v. 90 , no. 7, pt. I, p. 609-611.

Rubin, Meyer, Gargulinski, L.K., and McGeehin, J.P., 1987, Hawaiian radiocarbon dates, chap. 9 in v. 1 of Decker, R.W., Wright, T.L., and Stauffer, P.H., eds., Volcanism in Hawaii: U.S. Geological Survey Professional Paper 1350, p. 213-242.

Stearns, H.T., and Macdonald, G.A., 1946, Geology and groundwater resources of the Island of Hawaii: Hawaii Division of Hydrography Bulletin 9, 363 p.

Swanson, D.A., and Christiansen, R.L., 1973, Tragic base surge in 1790 at Kilauea Volcano: Geology, v. 1 , no. 2 , p. $83-86$.
Tilling, R.I., Koyanagi, R.Y., Lipman, P.W., Lockwood, J.P., Moore, J.G., and Swanson, D.A., 1976, Earthquake and related catastrophic events, Island of Hawaii, November 29, 1975: a preliminary report: U.S. Geological Survey Circular 740, 33 p.

U.S. Geological Survey, 1931, Hawaiian damage from tidal waves: Volcano Letter, no. 321,4 p.

U.S. Geological Survey, 1977, Natural hazards on the Island of Hawail: Washington, D.C., U.S. Geological Survey, $15 \mathrm{p}$.

Wentworth, C.K., 1938, Ash formations of the Island Hawaii: Honolulu, 3d Special Report of the Hawaiian Volcano Observatory, Hawaiian Volcano Research Association, $183 \mathrm{p}$.

Wieczorek, G.F., Jibson, R.W., Wilson, R.C., and Buchanan-Banks, J.M., 1982, Geotechnical properties of ash deposits near Hilo, Hawaii: U.S. Geological Survey Open-File Report 82-279, 27 p.

Wolfe, E.W, Neal, C.A., Banks, N.G., and Duggan, T.J., 1988, Geologic observations and chronology of eruptive events, chap. 1 in Wolfe, E.W., ed., The Puu Oo eruption of Kilauea Volcano, Hawail, episodes 1 through 20, January 3, 1983, through June 8, 1984: U.S. Geological Survey Professional Paper 1463, p. 1-97.

Wright, T.L., 1971, Chemistry of Kilauea and Mauna Loa lava in space and time: U.S. Geological Survey Professional Paper 735, 40 p. 
Table 1. Radiocarbon ages from charcoal samples in Hilo and parts of Piihonua and Mountain View quadrangles, Island of Hawaii 1

[Quadrangles: H, Hilo; P, Piihonua; M, Mountain View]

\begin{tabular}{|c|c|c|c|c|c|}
\hline Map No. 2 & Sample No. & Quadrangle & Map unit ${ }^{3}$ & Age, in ka & Collector 4 \\
\hline$(5)$ & 6 W3881 & $M$ & kipvt & $0.26 \pm 0.07$ & P.W. Lipman \\
\hline $\mathrm{R} 1$ & W5098 & $P$ & Ik2ku & $0.57 \pm 0.06$ & J.P. Lockwood and B.M. Lockwood \\
\hline $\mathrm{R} 2$ & W4631 & $\mathrm{H}$ & lk2kk & $1.11 \pm 0.06$ & \\
\hline R3 & W5597 & $\mathrm{H}$ & lk2kk & $1.14 \pm 0.30$ & \\
\hline R4 & W4343 & $\mathrm{H}$ & lk2kk & $1.28 \pm 0.07$ & J.P. Lockwood and J.M. Buchanan-Banks \\
\hline R5 & W4981 & $\mathrm{H}$ & Ik2pf4 & $1.47 \pm 0.05$ & J.P. Lockwood \\
\hline R6 & W5670 & $\mathrm{H}$ & Ik2ws & $1.50 \pm 0.20$ & \\
\hline R7 & W5278 & $H$ & Ik2ws & $1.74 \pm 0.10$ & \\
\hline R8 & W4621 & $\mathrm{H}$ & Ik2pu & $3.14 \pm 0.07$ & J.M. Buchanan-Banks and N.G. Banks \\
\hline R9 & W4629 & $\mathrm{H}$ & lk2pu & $3.36 \pm 0.08$ & \\
\hline R10 & W4624 & $P$ & Ik2pu & $3.38 \pm 0.08$ & J.M. Buchanan-Banks and N.G. Banks \\
\hline R11 & 6 W3803 & $\mathrm{H}$ & lk2pu & $4.05 \pm 0.05$ & J.P. Lockwood \\
\hline $\mathrm{R} 12$ & W5077 & $\mathrm{H}$ & Ik2wi & $4.41 \pm 0.12$ & \\
\hline $\mathrm{R} 13$ & W4536 & $M$ & Ik2ps & $5.25 \pm 0.10$ & J.P. Lockwood \\
\hline $\mathrm{R} 14$ & W4969 & $P$ & Ik2ar & $8.03 \pm 0.07$ & J.P. Lockwood \\
\hline $\mathrm{R} 15$ & W4975 & $P$ & Ik2ad4 & $9.02 \pm 0.13$ & J.P. Lockwood \\
\hline $\mathrm{R} 16$ & $7 W 6226$ & $H$ & Ik2ad1 & $9.02 \pm 0.12$ & J.P. Lockwood \\
\hline $\mathrm{R} 17$ & W4884 & $\mathrm{H}$ & Ik2wh & $9.78 \pm 0.14$ & \\
\hline $\mathrm{R} 18$ & W5072 & $P$ & Ik2my & $10.32 \pm 0.07$ & \\
\hline$R 19$ & W4623 & $\mathrm{H}$ & $1 k 2 r f$ & $10.61 \pm 0.15$ & \\
\hline R20 & W4627 & $\mathrm{H}$ & Ik2wa & $13.53 \pm 0.18$ & \\
\hline $\mathrm{R} 21$ & W4971 & $\mathrm{H}$ & Ik2wa & $14.08 \pm 0.15$ & \\
\hline $\mathrm{R} 22$ & W4973 & H & Ik2wa & $14.37 \pm 0.19$ & J.M. Buchanan-Banks and V.C. Taylor \\
\hline $\mathrm{R} 23$ & W4620 & $H$ & Ik2wa & $14.50 \pm 0.20$ & J.M. Buchanan-Banks and N.G. Banks \\
\hline R24 & W4977 & $H$ & Ik2wa & $14.53 \pm 0.12$ & \\
\hline $\mathrm{R} 25$ & W4890 & $\mathrm{H}$ & Ik1wy & $23.84 \pm 0.60$ & \\
\hline $\mathrm{R} 26$ & W5075 & $P$ & Ik1hr & $24.24 \pm 0.50$ & \\
\hline
\end{tabular}

1 See Buchanan-Banks and others (1989) for descriptions of charcoal materials and collection sites; ages from Rubin and others (1987). 2 See map sheet for location.

3 See Description of Map Units for explanation of map-unit symbols.

4 Samples collected by author except as noted.

5 Collection site south of map area; see Holcomb (1987) fig 12.5 I for location.

6 See Kelley and others (1979) for description of charcoal materials and collection sites.

7 J.P. Lockwood, oral commun., 1990. 
Table 2. Chemical analyses of lava flows from Kilauea, Mauna Loa, and Mauna Kea Volcanoes, Island of Hawaii

[Analyses performed at USGS, Reston, Va., as follows: Z.A. Hamlin, W214528-W214537; Hezekiah Smith, W218520-W218526, W227768-W227793, W231911, W231912, and W240444-W240446; J.R. Gillison, W214326-W215334; Debby Kay, W220495-W220498; Leo Mei, W229943-W229950]

\begin{tabular}{|c|c|c|c|c|c|c|c|c|c|c|c|c|c|c|c|}
\hline \multirow{3}{*}{$\begin{array}{l}\text { Volcano } \\
\text { Formation } \\
\text { Map No. }{ }^{1}\end{array}$} & \multirow{2}{*}{\multicolumn{2}{|c|}{$\begin{array}{c}\text { KILAUEA } \\
\text { Puna Basalt }\end{array}$}} & \multicolumn{13}{|c|}{ MAUNA LOA } \\
\hline & & & \multicolumn{13}{|c|}{ Kau Basalt } \\
\hline & $\mathrm{Cl}$ & $\mathrm{C} 2$ & C3 & $\mathrm{C} 4$ & $\mathrm{C} 5$ & C6 & $\mathrm{C7}$ & $\mathrm{C} 8$ & $\mathrm{Cg}$ & $\mathrm{C} 10$ & $\mathrm{C} 11$ & $\mathrm{C} 12$ & $\mathrm{C} 13$ & $\mathrm{C14}$ & $\mathrm{C} 15$ \\
\hline Lab No. (W) & 220496 & 229949 & 215326 & 229944 & 227782 & 214535 & 229946 & 227788 & 227778 & 227779 & 227780 & 215333 & 240444 & 227786 & 227792 \\
\hline Map unit ${ }^{2}$ & kipvt & kipvt & Ik21881 & Ik2ku & Ik2kk & Ik2kk & Ik2kk & $1 \mathrm{k} 2 \mathrm{pf} 4$ & $1 \mathrm{k} 2 \mathrm{pf} 4$ & |k2fpt & 1k2pf4 & Ik2pf3 & Ik2pf3 & 1k2pf2 & Ik2pf2 \\
\hline $\mathrm{SiO}_{2} \ldots \ldots \ldots \ldots$ & 51.40 & 50.20 & 52.40 & 51.40 & 51.20 & 51.90 & 50.70 & 48.90 & 49.90 & 49.90 & 50.20 & 53.60 & 51.20 & 49.60 & 50.60 \\
\hline $\mathrm{Al}_{2} \mathrm{O}_{3} \ldots \ldots \ldots \ldots \ldots$ & 14.00 & 13.50 & 13.80 & 14.00 & 13.60 & 13.70 & 13.60 & 11.80 & 12.60 & 12.70 & 12.10 & 14.60 & 13.80 & 12.70 & 13.00 \\
\hline $\mathrm{Fe}_{2} \mathrm{O}_{3} \ldots$ & 2.00 & 3.50 & 1.70 & 2.70 & 2.30 & 2.40 & 2.30 & 2.00 & 2.30 & 2.10 & 2.90 & 2.10 & 4.10 & 1.60 & 2.50 \\
\hline FeO......................... & 9.40 & 7.50 & 9.10 & 8.20 & 8.80 & 8.60 & 9.40 & 9.40 & 8.90 & 8.90 & 8.20 & 9.50 & 7.80 & 9.40 & 9.00 \\
\hline $\mathrm{MgO} \ldots \ldots \ldots \ldots . . . . . .$. & 7.40 & 7.40 & 8.00 & 7.00 & 7.50 & 7.20 & 7.20 & 13.20 & 10.30 & 10.70 & 11.30 & 7.40 & 7.10 & 10.90 & 9.70 \\
\hline $\mathrm{CaO}$ & 10.90 & 10.90 & 9.80 & 10.40 & 10.40 & 10.20 & 10.20 & 8.90 & 9.80 & 9.80 & 9.40 & 7.00 & 10.10 & 9.60 & 9.80 \\
\hline $\mathrm{Na}_{2} \mathrm{O} \ldots \ldots \ldots \ldots$ & 2.20 & 2.20 & 2.20 & 2.30 & 2.20 & 2.10 & 2.20 & 1.80 & 2.00 & 2.00 & 1.90 & 2.10 & 2.30 & 2.00 & 2.10 \\
\hline $\mathrm{K}_{2} \mathrm{O} \ldots \ldots \ldots \ldots \ldots$ & .40 & .10 & .34 & .48 & .32 & .41 & .43 & .22 & .34 & .30 & .28 & .44 & .46 & .24 & .24 \\
\hline $\mathrm{H}_{2} \mathrm{O}^{+} \ldots \ldots \ldots \ldots \ldots$ & .38 & .26 & .26 & .20 & .11 & .37 & .53 & .39 & .35 & .52 & .50 & .40 & .11 & .28 & .24 \\
\hline $\mathrm{H}_{2} \mathrm{O}^{-} \ldots \ldots \ldots \ldots \ldots$ & .27 & .10 & .10 & .04 & .06 & .11 & .28 & .07 & .04 & .01 & .06 & .03 & .04 & .08 & .07 \\
\hline $\mathrm{TiO}_{2} \ldots \ldots$ & 2.50 & 2.40 & 1.70 & 2.10 & 2.00 & 2.10 & 2.10 & 1.60 & 1.80 & 1.80 & 1.70 & 1.90 & 2.20 & 1.70 & 1.90 \\
\hline $\mathrm{P}_{2} \mathrm{O}_{5} \ldots \ldots \ldots \ldots$ & .28 & .25 & .26 & .27 & .27 & .27 & .25 & .24 & .25 & .26 & .24 & .18 & .30 & .25 & .27 \\
\hline $\mathrm{MnO}$ & .15 & .16 & .18 & .16 & .17 & .17 & .17 & .17 & .16 & .16 & .16 & .23 & .18 & .16 & .17 \\
\hline $\mathrm{CO}_{2} \ldots \ldots \ldots \ldots \ldots$ & .02 & .01 & .01 & .01 & .03 & .01 & .01 & .07 & .05 & .07 & .08 & .05 & .01 & .07 & .06 \\
\hline Total............... & 101.30 & 98.48 & 99.85 & 99.26 & 98.96 & 99.54 & 99.37 & 98.76 & 98.79 & 99.22 & 99.02 & 99.53 & 99.70 & 98.58 & 99.65 \\
\hline
\end{tabular}


Table 2. Chemical analyses of lava flows from Kilauea, Mauna Loa, and Mauna Kea Volcanoes, Island of Hawaii-Continued

\begin{tabular}{|c|c|c|c|c|c|c|c|c|c|c|c|c|c|c|c|}
\hline \multirow{3}{*}{$\begin{array}{l}\text { Volcano } \\
\text { Formation } \\
\text { Map No. }{ }^{1}\end{array}$} & \multicolumn{15}{|c|}{ MAUNA LOA } \\
\hline & \multicolumn{15}{|c|}{ Kau Basalt } \\
\hline & $\mathrm{C} 16$ & $\mathrm{C} 17$ & $\mathrm{C} 18$ & $\mathrm{C} 19$ & $\mathrm{C} 20$ & $\mathrm{C} 21$ & $\mathrm{C} 22$ & $\mathrm{C} 23$ & $\mathrm{C} 24$ & $\mathrm{C} 25$ & $\mathrm{C} 26$ & $\mathrm{C} 27$ & $\mathrm{C} 28$ & C29 & C30 \\
\hline Lab No. (W) & 215328 & 227793 & 227789 & 227776 & 227770 & 227768 & 215327 & 218525 & 227790 & 220497 & 227791 & 214536 & 227787 & 227773 & 227771 \\
\hline Map unit 2 & lk2pf1 & |k2pf1 & Ik2mv & Ik2ws & Ik2ho & Ik2pu & Ik2pu & Ik2wi & Ik2ps & |k2ol & Ik2ol & Ik2ks & Ik2ks & $1 k 2 w r$ & Ik2ai \\
\hline $\mathrm{SiO}_{2} \ldots \ldots$ & 50.80 & 51.10 & 50.50 & 50.80 & 50.30 & 50.70 & 51.60 & 51.40 & 47.40 & 50.80 & 50.00 & 51.10 & 50.60 & 50.20 & 50.70 \\
\hline $\mathrm{Al}_{2} \mathrm{O}_{3}$. & 13.90 & 13.60 & 13.50 & 13.20 & 13.60 & 13.80 & 14.10 & 14.00 & 9.80 & 13.80 & 13.30 & 13.70 & 13.50 & 13.50 & 13.50 \\
\hline $\mathrm{Fe}_{2} \mathrm{O}_{3}$ & 1.30 & 2.40 & 2.50 & 3.10 & 4.90 & 1.40 & 2.00 & 2.30 & 2.30 & 2.60 & 2.50 & 2.90 & 2.30 & 2.70 & 2.90 \\
\hline $\mathrm{FeO} \ldots . .$. & 9.70 & 9.70 & 9.70 & 8.50 & 7.40 & 10.00 & 8.80 & 8.80 & 9.70 & 8.40 & 9.30 & 8.30 & 9.20 & 9.30 & 9.00 \\
\hline $\mathrm{MgO} \ldots . .$. & 6.40 & 6.70 & 7.50 & 7.70 & 6.60 & 7.30 & 7.20 & 7.40 & 18.40 & 9.00 & 8.90 & 7.40 & 7.90 & 7.90 & 7.20 \\
\hline $\mathrm{CaO} \ldots \ldots \ldots \ldots$ & 11.60 & 10.10 & 10.00 & 10.20 & 10.40 & 10.20 & 10.40 & 10.00 & 7.50 & 9.90 & 10.00 & 10.00 & 10.00 & 10.30 & 10.20 \\
\hline $\mathrm{Na}_{2} \mathrm{O} \ldots$ & 2.20 & 2.40 & 2.30 & 2.00 & 2.20 & 2.20 & 2.10 & 2.30 & 1.50 & 2.20 & 2.20 & 2.10 & 2.20 & 2.20 & 2.30 \\
\hline $\mathrm{K}_{2} \mathrm{O} \ldots \ldots$ & .43 & .30 & .34 & .32 & .42 & .36 & .41 & .20 & .14 & .32 & .26 & .38 & .24 & .36 & .38 \\
\hline $\mathrm{H}_{2} \mathrm{O}^{+} \ldots$ & .43 & .47 & .43 & .46 & .39 & .70 & .48 & .53 & .46 & .66 & .37 & .40 & .37 & .18 & .21 \\
\hline $\mathrm{H}_{2} \mathrm{O}^{-} \ldots \ldots \ldots \ldots$ & .05 & .03 & .03 & .25 & .01 & .40 & .10 & .15 & .28 & .35 & .17 & .33 & .19 & .30 & .24 \\
\hline $\mathrm{TiO}_{2} \ldots \ldots \ldots$ & 1.80 & 2.20 & 2.10 & 2.00 & 2.10 & 2.10 & 1.70 & 2.00 & 1.40 & 2.00 & 2.00 & 2.10 & 2.00 & 2.10 & 2.20 \\
\hline $\mathrm{P}_{2} \mathrm{O}_{5}$ & .17 & .32 & .29 & .25 & .30 & .30 & .29 & .26 & .18 & .29 & .29 & .26 & .28 & .29 & .31 \\
\hline $\mathrm{MnO}$ & .21 & .18 & .18 & .17 & .17 & .17 & .19 & .17 & .17 & .16 & .17 & .16 & .17 & .17 & .17 \\
\hline $\mathrm{CO}_{2} \ldots \ldots$ & .01 & .08 & .06 & .09 & .02 & .04 & .01 & .02 & .03 & .04 & .07 & .01 & .08 & .09 & .03 \\
\hline Total..... & 99.00 & 99.58 & 99.43 & 99.04 & 98.81 & 99.67 & 99.38 & 99.53 & 99.26 & 100.52 & 99.53 & 99.14 & 99.03 & 99.59 & 99.34 \\
\hline
\end{tabular}


Table 2. Chemical analyses of lawa flows from Kilauea, Mauna Loa, and Mauna Kea Volcanoes, Island of Hawaii-Continued

\begin{tabular}{|c|c|c|c|c|c|c|c|c|c|c|c|c|c|c|c|}
\hline \multirow{3}{*}{$\begin{array}{l}\text { Volcano } \\
\text { Formation } \\
\text { Map No. }{ }^{1}\end{array}$} & \multicolumn{15}{|c|}{ MAUNA LOA } \\
\hline & \multicolumn{15}{|c|}{ Kau Basalt } \\
\hline & C31 & $\mathrm{C} 32$ & C33 & C34 & C35 & C36 & C37 & C38 & C39 & $\mathrm{C40}$ & $\mathrm{C} 41$ & $\mathrm{C42}$ & $\mathrm{C} 43$ & C44 & C45 \\
\hline Lab No. M) & 214534 & 227783 & 218526 & 227775 & 215334 & 227781 & 240446 & 229947 & 240445 & 218522 & 229943 & 227772 & 227774 & 227777 & 215329 \\
\hline Map unit 2 & Ik2ar & |k2ad4 & |k2ad3 & |k2ads & Hk2ad2 & Ik2ad2 & |k2ad2 & |k2ad1 & |k2ad1 & Ik2wh & |k2wh & $1 \mathrm{k} 2 \mathrm{my}$ & $1 k 2 m y$ & Ik2mo & Ik2rf \\
\hline $\mathrm{SO}_{2} \ldots \ldots \ldots \ldots$ & 50.60 & 47.60 & 49.50 & 48.10 & 50.50 & 48.50 & 48.20 & 47.70 & 48.50 & 50.80 & 50.00 & 49.90 & 50.90 & 50.40 & 51.40 \\
\hline $\mathrm{Al}_{2} \mathrm{O}_{3} \ldots \ldots$ & 13.20 & 10.30 & 11.60 & 10.70 & 12.50 & 11.60 & 10.80 & 10.60 & 12.40 & 13.90 & 13.80 & 13.70 & 13.60 & 13.30 & 13.30 \\
\hline $\mathrm{Fe}_{2} \mathrm{O}_{3} \ldots \ldots$ & 3.70 & 2.60 & 2.20 & 2.20 & 2.40 & 2.90 & 2.50 & 5.20 & 3.10 & 3.00 & 3.10 & 2.70 & 3.80 & 2.50 & 2.30 \\
\hline 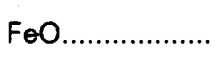 & 7.80 & 10.10 & 9.40 & 10.00 & 8.40 & 9.20 & 9.20 & 6.50 & 9.00 & 8.70 & 8.60 & 9.00 & 8.20 & 9.20 & 8.60 \\
\hline 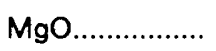 & 9.70 & 16.60 & 12.60 & 16.60 & 11.00 & 13.80 & 18.20 & 15.80 & 14.40 & 6.80 & 6.80 & 6.80 & 7.90 & 7.60 & 9.40 \\
\hline $\mathrm{CaO}$ & 9.40 & 7.70 & 8.60 & 8.00 & 9.20 & 8.60 & 7.60 & 8.00 & 8.60 & 9.80 & 9.60 & 9.90 & 10.40 & 10.20 & 9.60 \\
\hline $\mathrm{Na}_{2} \mathrm{O} \ldots \ldots \ldots$ & 2.10 & 1.60 & 1.90 & 1.60 & 1.90 & 1.70 & 1.60 & 1.40 & 1.70 & 2.30 & 2.20 & 2.30 & 2.00 & 2.00 & 1.80 \\
\hline $\mathrm{K}_{2} \mathrm{O} \ldots \ldots$ & .37 & .20 & .12 & .20 & .31 & .18 & .27 & .22 & .24 & .14 & .61 & .34 & .28 & .30 & .33 \\
\hline $\mathrm{H}_{2} \mathrm{O}^{+} \ldots \ldots \ldots \ldots$ & .39 & .25 & .74 & .41 & .53 & .20 & .38 & .66 & .59 & .65 & .83 & .51 & .59 & .48 & .48 \\
\hline $\mathrm{H}_{2} \mathrm{O}^{-} \ldots \ldots \ldots \ldots \ldots$ & .25 & .14 & .27 & .1 & .2 & .1 & .17 & .74 & .33 & .3 & .57 & .79 & .31 & .20 & .12 \\
\hline $\mathrm{THO}_{2}$ & 2.00 & 1.50 & 1.80 & 1.60 & 1.80 & 1.70 & 1.50 & 1.60 & 1.80 & 2.20 & 2.30 & 2.20 & 2.10 & 2.10 & 1.80 \\
\hline $\mathrm{P}_{2} \mathrm{O}_{5} \ldots \ldots$ & .24 & .19 & .21 & .20 & .14 & .26 & .20 & .20 & .16 & .25 & .29 & .28 & .26 & .27 & .23 \\
\hline $\mathrm{MnO} \ldots \ldots \ldots \ldots \ldots$ & .16 & .18 & .16 & .17 & .20 & .18 & .17 & .17 & .18 & .17 & .17 & .17 & .17 & .17 & .20 \\
\hline $\mathrm{CO}_{2} \ldots \ldots$ & .01 & .07 & .05 & .06 & .01 & .03 & .01 & .01 & .01 & .06 & .02 & .02 & .08 & .09 & .01 \\
\hline Total... & 99.92 & 99.03 & 99.15 & 100.00 & 99.16 & 98.99 & 101.01 & 98.80 & 101.01 & 99.11 & 98.89 & 98.61 & 100.59 & 98.81 & 99.57 \\
\hline
\end{tabular}


Tabłe 2. Chemical analyses of lava flows from Kilauea, Mauna Loa, and Mauna Kea Volcanoes, Island of Hawaii-Continued

\begin{tabular}{|c|c|c|c|c|c|c|c|c|c|c|c|c|c|c|c|c|}
\hline \multirow{3}{*}{$\begin{array}{l}\text { Volcano } \\
\text { Formation } \\
\text { Map No. }{ }^{1}\end{array}$} & \multicolumn{16}{|c|}{ MAUNA LOA } \\
\hline & \multicolumn{10}{|c|}{ Kau Basalt } & \multicolumn{6}{|c|}{ Kahuku Basalt } \\
\hline & $\mathrm{C} 46$ & $\mathrm{C} 47$ & $\mathrm{C} 48$ & $\mathrm{C} 49$ & $\mathrm{C} 50$ & C51 & C52 & C53 & C54 & C55 & C56 & C57 & C58 & C59 & C60 & C61 \\
\hline Lab No. MV) & 227784 & 227785 & 215331 & 229945 & 229948 & 229950 & 214533 & 215330 & 218520 & 231911 & 220495 & 231912 & 214537 & 215332 & 218524 & 218523 \\
\hline Map unit 2 & $\| k 21 \mathrm{r}$ & $|k 2:| r$ & $|k 2| r$ & $\mid \mathrm{k} 2 \mathrm{lr}$ & Ik2ka & lk2ka & Ik2wa & Ik2wa & Ik2wa & Ik2wa & $\mid k 1 m p$ & Ik1he & Ik1hf & lk1wy & lk1wo & |k1hr \\
\hline $\mathrm{SiO}_{2} \ldots$ & 45.90 & 47.50 & 48.40 & 49.80 & 47.80 & 47.20 & 50.70 & 52.10 & 50.50 & 49.10 & 51.60 & 46.90 & 47.10 & 50.60 & 49.80 & 49.90 \\
\hline $\mathrm{Al}_{2} \mathrm{O}_{3} \ldots \ldots$ & 8.00 & 10.10 & 9.10 & 12.00 & 8.70 & 8.10 & 13.80 & 14.50 & 14.00 & 13.80 & 14.80 & 11.60 & 11.00 & 14.50 & 13.20 & 14.00 \\
\hline $\mathrm{MgO}$ & 24.00 & 17.20 & 20.30 & 11.80 & 21.70 & 22.40 & 7.20 & 7.20 & 7.20 & 7.20 & 7.80 & 14.20 & 17.80 & 7.50 & 8.60 & 8.00 \\
\hline $\mathrm{CaO} \ldots \ldots \ldots \ldots$ & 6.50 & 8.40 & 7.50 & 9.70 & 7.50 & 7.50 & 9.90 & 10.00 & 9.80 & 9.20 & 9.60 & 8.60 & 8.20 & 10.00 & 9.40 & 9.10 \\
\hline $\mathrm{Na}_{2} \mathrm{O}$ & 1.10 & 1.50 & 1.20 & 1.70 & 1.10 & 1.10 & 2.10 & 2.00 & 2.20 & 1.90 & 2.30 & 1.60 & 1.50 & 1.90 & 2.00 & 2.00 \\
\hline $\mathrm{K}_{2} \mathrm{O} \ldots \ldots \ldots \ldots$ & .12 & .16 & .26 & .01 & .19 & .11 & .45 & .42 & .12 & .38 & .41 & .10 & .14 & .34 & .12 & .12 \\
\hline $\mathrm{H}_{2} \mathrm{O}^{+} \ldots \ldots \ldots \ldots$ & .61 & .53 & .28 & .63 & .35 & .57 & .97 & .94 & .57 & 1.70 & 1.00 & 1.10 & .60 & 1.30 & 1.30 & 1.60 \\
\hline $\mathrm{MnO} \ldots \ldots \ldots \ldots \ldots$ & .17 & .17 & .21 & .16 & .16 & .17 & .18 & .20 & .18 & .17 & .14 & .17 & .16 & .22 & .18 & .19 \\
\hline $\mathrm{CO}_{2} \ldots \ldots \ldots$ & .06 & .08 & .08 & .01 & .01 & .01 & .01 & .04 & .04 & .03 & .06 & .01 & .01 & .02 & .06 & .03 \\
\hline Total.. & 100.00 & 98.85 & 100.02 & 99.55 & 99.91 & 99.72 & 99.98 & 101.08 & 99.21 & 98.76 & 101.47 & 98.64 & 100.03 & 100.44 & 99.12 & 99.26 \\
\hline
\end{tabular}


Table 2. Chemical analyses of lava flows from Kilauea, Mauna Loa, and Mauna Kea Volcanoes, Island of Hawali-Continued

\begin{tabular}{|c|c|c|c|c|c|c|c|c|}
\hline \multirow{3}{*}{$\begin{array}{l}\text { Volcano } \\
\text { Formation } \\
\text { Map No. }{ }^{1}\end{array}$} & \multicolumn{8}{|c|}{ MAUNA KEA } \\
\hline & \multicolumn{8}{|c|}{ Hamakua Volcanics } \\
\hline & $\mathrm{C} 62$ & $\mathrm{C} 63$ & C64 & $\mathrm{C} 65$ & C66 & $\mathrm{C} 67$ & $\mathrm{C} 68$ & C69 \\
\hline Lab No. (W) & 227769 & 220498 & 214529 & 214528 & 214532 & 214531 & 214530 & 218521 \\
\hline Map unit 2 & khpi & khw6 & khw5 & khkg & khw4 & khw3 & khw2 & khw1 \\
\hline $\mathrm{SiO}_{2} \ldots \ldots \ldots \ldots$ & 44.20 & 47.10 & 45.00 & 45.10 & 44.10 & 43.60 & 45.60 & 40.70 \\
\hline $\mathrm{Al}_{2} \mathrm{O}_{3} \ldots \ldots$ & 14.20 & 14.20 & 15.10 & 15.80 & 14.60 & 14.60 & 14.70 & 13.30 \\
\hline $\mathrm{Fe}_{2} \mathrm{O}_{3} \ldots \ldots$ & 5.20 & 4.00 & 4.50 & 4.30 & 3.80 & 8.60 & 3.90 & 9.30 \\
\hline $\mathrm{FeO} \ldots$ & 10.00 & 10.40 & 9.40 & 10.50 & 11.50 & 7.40 & 10.00 & 6.80 \\
\hline $\mathrm{MgO} \ldots \ldots \ldots \ldots$ & 6.00 & 5.10 & 6.20 & 5.80 & 5.40 & 4.80 & 5.70 & 10.70 \\
\hline $\mathrm{CaO} \ldots$ & 9.00 & 10.00 & 9.50 & 7.90 & 8.80 & 7.60 & 9.90 & 6.40 \\
\hline $\mathrm{Na}_{2} \mathrm{O} \ldots \ldots \ldots \ldots \ldots$ & 2.10 & 2.70 & 2.50 & 2.60 & 2.30 & 2.00 & 2.70 & 1.50 \\
\hline $\mathrm{K}_{2} \mathrm{O} \ldots \ldots \ldots \ldots$ & .76 & .69 & .80 & .89 & .57 & .81 & .84 & .56 \\
\hline $\mathrm{H}_{2} \mathrm{O}^{+} \ldots \ldots \ldots \ldots$ & 2.60 & 1.50 & 1.10 & 1.00 & 1.50 & 2.30 & .51 & 3.50 \\
\hline $\mathrm{H}_{2} \mathrm{O}^{-} \ldots \ldots \ldots \ldots$ & .25 & .95 & .67 & .53 & 1.00 & 2.20 & .26 & 2.00 \\
\hline $\mathrm{TiO}_{2} \ldots \ldots \ldots \ldots$ & 3.70 & 1.60 & 4.00 & 4.30 & 4.70 & 4.70 & 4.20 & 3.20 \\
\hline $\mathrm{P}_{2} \mathrm{O}_{5} \ldots \ldots \ldots \ldots \ldots$ & .51 & .46 & .40 & .49 & .48 & .50 & .43 & .48 \\
\hline MnO............... & .22 & .17 & .20 & .20 & .21 & .21 & .20 & .22 \\
\hline $\mathrm{CO}_{2} \ldots \ldots \ldots \ldots \ldots$ & .02 & .02 & .02 & .01 & .01 & .01 & .01 & .03 \\
\hline Total............. & 98.76 & 98.89 & 99.39 & 99.42 & 98.97 & 99.33 & 98.95 & 98.69 \\
\hline
\end{tabular}


Table 3. Paleomagnetic data from lava flows in Hilo and parts of Piihonua and Mountain View quadrangles, Island of Hawaii [Quadrangle: H, Hilo; P. Piihonua; M, Mountain View. Parameters of paleomagnetic directions: D, declination; I, inclination; n, number of specimens used for final site mean, after elimination of anomalous specimens; k, estimate within-site precision; $\alpha 95,95$-percent confidence circle, in degrees. ?, tentative correlation]

\begin{tabular}{|c|c|c|c|c|c|c|c|c|c|}
\hline $\begin{array}{l}\text { Map } \\
\text { N0. }\end{array}$ & Site No. ${ }^{2}$ & $\begin{array}{l}\text { Quad- } \\
\text { rangle }\end{array}$ & $\begin{array}{l}\text { Map } \\
\text { unit }^{3}\end{array}$ & $\mathrm{D}$ & 1 & $n$ & k & $\alpha 95$ & Comments \\
\hline $\mathrm{PI}$ & $+8 B 001$ & $M$ & kipvt & 2.0 & 43.3 & 12 & 701 & 1.6 & From Holcomb and others (1986) and Holcomb (1987, fig. $12.5 \mathrm{~N}$. \\
\hline$P 2$ & $1 \mathrm{~A} 072$ & $H$ & |k21881 & 7.6 & 34.1 & 11 & 605 & 1.9 & Same flow as P3. \\
\hline P3 & $1 \mathrm{~A} 466$ & $\mathrm{H}$ & |k21881 & 7.2 & 36.4 & 9 & 461 & 2.4 & Same flow as $P 2$. \\
\hline P4 & $-9 B 061$ & $P$ & Ik2ku & 5.1 & 40.2 & 11 & 684 & 1.8 & From D.E. Champion (written commun., 1988); same flow as P5. \\
\hline P5 & $1 \mathrm{~A} 442$ & $P$ & Ik2ku & 7.5 & 36.8 & 11 & 476 & 2.1 & Same flow as P4. \\
\hline P6 & $-9 \mathrm{~B} 049$ & $\mathrm{H}$ & lk2kk & .1 & 18.9 & 12 & 699 & 1.6 & $\begin{array}{l}\text { From Holcomb and others (1986), modified by D.E. Champion twritten } \\
\text { commun., 1988); same flow as P7 and P8. }\end{array}$ \\
\hline P7 & 1 A038 & $\mathrm{H}$ & lk2kk & 2.1 & 20.2 & 12 & 309 & 2.5 & Same flow as P6 and P8; overlies $P 26$ at collection site. \\
\hline P8 & $1 \mathrm{A478}$ & $\mathrm{H}$ & Ik2kk & 1.0 & 21.1 & 11 & 395 & 2.3 & $\begin{array}{l}\text { Flow underlies } P 2 \text { and overlies } P 31 \text { at their collection sites; same flow as } \\
\text { P6 and P7. }\end{array}$ \\
\hline P9 & $-9 \mathrm{~B} 037$ & $\mathrm{H}$ & Ik2pf4 & 357.7 & 25.7 & 12 & 370 & 2.3 & $\begin{array}{l}\text { From Holcomb and others (1986) modified by D.E. Champion (written } \\
\text { commun., 1988); same map unit as P10-P12. }\end{array}$ \\
\hline P10 & $17 B 409$ & $H$ & Ik2pf3 & 1.4 & 24.3 & 12 & 514 & 1.9 & Same map unit as $P 9, P 11$, and $P 12$. \\
\hline P11 & $17 B 421$ & $\mathrm{H}$ & lk2pf2 & 2.8 & 24.4 & 12 & 912 & 1.4 & Same map unit as $P 9, P 10$, and $P 12$. \\
\hline $\mathrm{P} 12$ & 128115 & $\mathrm{H}$ & lk2pf1 & 359.9 & 21.1 & 10 & 682 & 1.9 & Same map unit as P9-P11. \\
\hline $\mathrm{P} 13$ & $17 B 373$ & $\mathrm{H}$ & Ik2ws & 3.0 & 16.6 & 12 & 921 & 1.4 & \\
\hline P14 & $16 A 308$ & $P$ & Ik2ho & .6 & 25.7 & 10 & 869 & 1.6 & \\
\hline $\mathrm{P} 15$ & $+8 B 433$ & $H$ & Ik2pu & 4.5 & 33.4 & 12 & 1,467 & 1.1 & $\begin{array}{l}\text { From Holcomb and others (1986), modified by D.E. Champion (weritten } \\
\text { commun., 1988); same flow as P16-P18. }\end{array}$ \\
\hline P16 & $1 \mathrm{~A} 062$ & $H$ & Ik2pu & 8.7 & 38.4 & 10 & 684 & 1.8 & Underlies Ik21881 at collection site; same flow as $\mathrm{P} 15, \mathrm{P} 17$, and $\mathrm{P} 18$. \\
\hline P17 & $1 \mathrm{~A} 136$ & $H$ & Ik2pu & 10.9 & 38.8 & 6 & 988 & 2.1 & Same flow as P15, P16, and P18. \\
\hline P18 & $1 \mathrm{~A} 274$ & $P$ & Ik2pu & 11.3 & 35.2 & 12 & 702 & 1.6 & Same flow as P15-P17. \\
\hline $\mathrm{P} 19$ & /2A419 & $H$ & Ik2wi & 6.2 & 41.5 & 11 & 1,259 & 1.3 & \\
\hline P20 & $1 \mathrm{~A} 298$ & $M$ & Ik2ps & 17.2 & 37.1 & 10 & 234 & 3.2 & \\
\hline$P 21$ & /6A331 & $\mathrm{H}$ & Ik2ks & 359.0 & 37.2 & 10 & 443 & 2.3 & \\
\hline
\end{tabular}


Table 3. Paleomagnetic data from lava flows in Hilo and parts of Piihonua and Mountain View quadrangles, Island of Hawaii-Continued

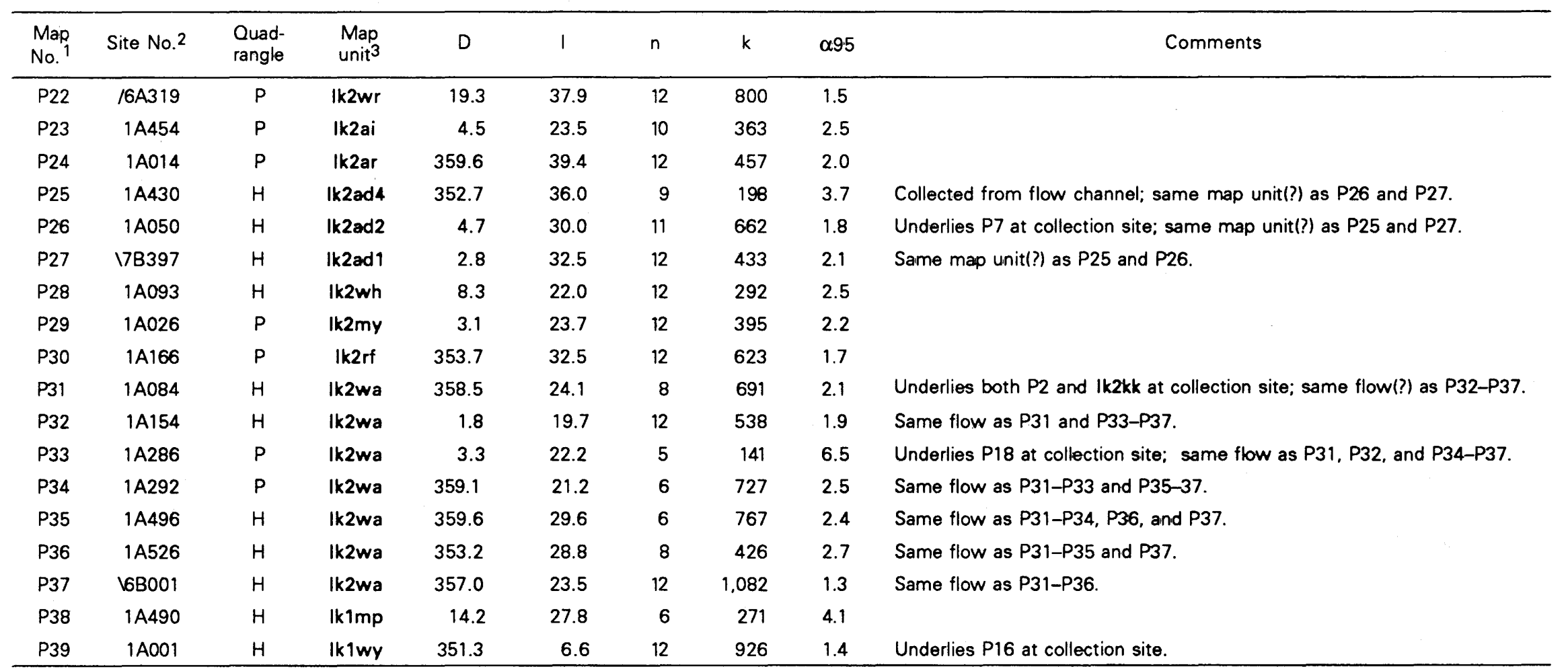

1 See map for location of sample site.

2 Samples collected by M.O. McWilliams and analyzed at Stanford University, Calif., except: (t), samples collected by D.E. Champion, R.T. Holcomb, and M.O. McWilliams; and (-), samples collected by D.E. Champion and R.T. Holcomb. U. samples collected by J.P. Lockwood and N. by D.E. Champion, and analyzed by D.E. Champion, at USGS, Mento Park, Calif.

3 See Description of Map Units for explanation of map-unit symbols. 

. 
